\title{
The Australian Food and Health Dialogue - the implications of the sodium recommendation for pasta sauces
}

\author{
Helen Trevena ${ }^{1,2, *}$, Elizabeth Dunford ${ }^{1}$, Bruce Neal $^{1}$ and Jacqueline Webster ${ }^{1}$ \\ 'The George Institute for Global Health, University of Sydney, PO Box M201, Missenden Road, Camperdown, \\ Sydney, NSW 2050, Australia: ${ }^{2}$ School of Exercise and Nutrition Sciences, Deakin University, Melbourne, \\ Victoria, Australia
}

Submitted 4 November 2012: Final revision received 12 May 2013: Accepted 29 May 2013: First published online 18 July 2013

\begin{abstract}
Objective: To assess the change in Na content of Australian pasta sauces between 2008 and 2011. A secondary objective was to project the mean $\mathrm{Na}$ content of these same products in 2014 using the Australian Food and Health Dialogue Na commitment and compare projections with the 2012 UK Na target for pasta sauce. Design: Na data were collected from the product labels of pasta sauce products. Mean Na content was calculated for 2008 and 2011 and change assessed. Projected mean values for 2014 were derived by applying a 15\% reduction to the 2011 products above the 'action point' of $420 \mathrm{mg} \mathrm{Na} / 100 \mathrm{~g}$, consistent with the Food and Health Dialogue commitment (scenario 1). A $15 \%$ reduction was applied to products already below the 'action point' (scenario 2). Projections were compared with the 2012 UK target.

Setting: Na data for pasta sauce products in Australian supermarkets (JulySeptember) in 2008 and 2011.

Subjects: Not applicable.

Results: Data were available for 124 (2008) and 187 (2011) products, and mean Na levels were not significantly different ( $451 \mathrm{mg} / 100 \mathrm{~g} v .423 \mathrm{mg} / 100 \mathrm{~g} ; P=0 \cdot 16)$. The projected means (381 mg Na/100 g in scenario $1 ; 375 \mathrm{mg} \mathrm{Na} / 100 \mathrm{~g}$ in scenario 2) exceeded the $2012 \mathrm{UK}$ target $(330 \mathrm{mg} \mathrm{Na} / 100 \mathrm{~g})$ and to attain this would require a $22 \%$ reduction from 2011 levels.

Conclusions: There is little evidence that all Australian manufacturers of pasta sauces systematically reduced the $\mathrm{Na}$ content of their products between 2008 and 2011. Even if all manufacturers achieve the current voluntary commitment by 2014, average salt levels in Australian products would still be above the 2012 UK target.
\end{abstract}

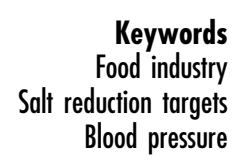

Keywords

Blood pressure
The economic and social burden of non-communicable diseases attributable to poor diet is substantial ${ }^{(1)}$. Compelling evidence associates excess dietary $\mathrm{Na}$ with raised blood pressure ${ }^{(2)}$, a preventable major risk factor for CVD which accounts for $34 \%$ of all deaths ${ }^{(3)}$. Almost a third of Australian adults have diagnosed hypertension (140/ $90 \mathrm{mmHg})^{(4)}$ but health risks increase before reaching this blood pressure threshold ${ }^{(5)}$.

Reducing blood pressure and the incidence of CVD around the world using programmes to lower population salt intake is a priority of the $\mathrm{WHO}^{(1)}$. As $75-80 \%$ of dietary salt in most Western diets comes from processed foods ${ }^{(6)}$, one component of many national strategies to reduce population salt intakes has been working with the food industry to reduce salt in processed foods ${ }^{(7)}$ and many countries have implemented voluntary Na reduction targets for major food categories. The $\mathrm{UK}^{(8)}, \mathrm{USA}^{(9)}$ and Canada ${ }^{(10)}$, for example, have each established more than sixty food $\mathrm{Na}$ reduction targets. In Australia, the
Australian Food and Health Dialogue (FHD), a joint government-industry-public health initiative ${ }^{(11)}$, has announced targets for seventeen food types in eight food categories.

Australians consume about $9 \mathrm{~g}$ salt/d (2800-4800 mg $\mathrm{Na} / \mathrm{d})^{(12,13)}$, which is much higher than physiological needs ${ }^{(6,14)}$. Hidden sources of salt in processed foods make it difficult for consumers to follow dietary guidelines ${ }^{(15)}$ when much of the average Australian's diet is comprised of processed foods. Bread, cereal and cerealbased products provide $49 \%$, meat and meat products $21 \%$, milk products and dishes $5 \%$ and savoury cooking sauces and condiments $8 \%{ }^{(16)}$ of salt intake from processed foods. Pasta sauces account for $75 \%$ of all savoury cooking sauces sold in Australian supermarkets ${ }^{(17)}$.

The 2012 UK Na reduction target for pasta sauce products is a mean of $330 \mathrm{mg} / 100 \mathrm{~g}^{(8)}$, and responsibility for the target was transferred from the Food Standards Agency (FSA) to the Public Health Responsibility Deal for 
England (Responsibility Deal) in March 2011 ${ }^{(18)}$. The USA $^{(9)}$ and Canada ${ }^{(10)}$ have set sales-weighted reduction targets: $330 \mathrm{mg} \mathrm{Na} / 100 \mathrm{~g}$ by 2014 in the USA and $320 \mathrm{mg}$ $\mathrm{Na} / 100 \mathrm{~g}$ with a maximum level of $520 \mathrm{mg} \mathrm{Na} / 100 \mathrm{~g}$ for any individual pasta sauce product by 2016 in Canada. The FHD commitment for pasta sauces announced in April 2011 uses neither a sales-weighted mean nor a maximum target. Instead it has set an 'action point' of $420 \mathrm{mg} \mathrm{Na} / 100 \mathrm{~g}$ and asks all manufacturers to voluntarily reduce the $\mathrm{Na}$ in any pasta sauce product with more than $420 \mathrm{mg} / 100 \mathrm{~g}$ in 2011 by $15 \%$ by the end of 2014 . In addition, for market leaders with leading products already below $420 \mathrm{mg} \mathrm{Na} / 100 \mathrm{~g}$, manufacturers are encouraged to 'seek opportunities' to further reduce $\mathrm{Na}$ levels ${ }^{(19)}$.

Monitoring $\mathrm{Na}$ reduction strategies is required to provide evidence that companies have reformulated their products and can be done by industry self-reports ${ }^{(19,20)}$, submission of sales data and recipes ${ }^{(19)}$ and use of food composition database $(s)^{(21)}$. Recent studies, based on food composition tables, have analysed the $\mathrm{Na}$ content of foods available in Australia $^{(22-25)}$ and have included foods such as bread ${ }^{(22)}$ that are significant contributors of $\mathrm{Na}$ to the diet. None, however, report specifically on pasta sauce products or project the FHD commitment. The temporal nature of the FHD commitment for pasta sauces provided a window of opportunity to project the mean $\mathrm{Na}$ content of the FHD commitment for this food type. The last published mean Na content of Australian pasta sauces, which also included pesto products, was $499 \mathrm{mg} / 100 \mathrm{~g}$ in $2008^{(26)}$. In comparison, 2009 data from the UK, for tomato pasta sauce products, showed a mean value of $320 \mathrm{mg} \mathrm{Na} / 100 \mathrm{~g}^{(27)}$. The primary objective of the present study was to assess the change in $\mathrm{Na}$ levels of Australian pasta sauce products by comparing 2008 and $2011 \mathrm{Na}$ content. A secondary objective was to project the mean Na content of these same products in 2014 using the FHD Na commitment and compare projections with the 2012 UK Na target for pasta sauce.

\section{Methods}

A systematic survey of the Na content of Australian pasta sauce products available in Australian supermarkets was undertaken in 2008 and 2011.

\section{Products included}

Pasta sauce products included were defined as ambient or fresh, where ambient products were those stored at room temperature and fresh products those requiring chilled storage. The definition included sauces that constitute a major part of a meal, and that are usually added to pasta, meat or vegetables and then heated.

\section{Data collection}

For each of the years 2008 and 2011, data were collected between July and September from the same five leading grocery stores (Coles, Woolworths, ALDI, IGA, Franklins) in Sydney, Australia. For each pasta sauce product, the manufacturer, brand and product name, as well as the $\mathrm{Na}$ content per $100 \mathrm{~g}$ were recorded. Data were obtained directly from the mandatory Nutrition Information Panel but where exactly the same product was for sale in more than one supermarket, it was recorded only once. Likewise, where the same product was presented in different pack sizes, only one entry was recorded. Data were entered into The George Institute's branded food composition database ${ }^{(21)}$ according to standardized methodology ${ }^{(28)}$. Data were screened to identify outliers and in each of the years a random selection of $5 \%$ of the pasta sauce records was generated and data relating to $\mathrm{Na}$ content and brand were verified with the original Nutrition Information Panel. Outliers and missing values were identified and discrepancies were followed up with the manufacturer directly, on the manufacturer website, or by verification against the original Nutrition Information Panel data.

\section{Grouping of manufacturers into types}

Manufacturers were grouped by type using percentage volume share available in the 2009 edition of Retail World's Australasian Grocery Guide ${ }^{(29)}$. The groupings of manufacturer type were: 'supermarket own label' (private label products with a total of $9 \%$ volume share $)^{(29)}$; 'leading manufacturers' (based on the top three national branded manufacturers who between them had almost $80 \%$ volume share) ${ }^{(29)}$; 'other manufacturers' (included national branded manufacturers with approximately total $5 \%$ volume share of pasta sauces) ${ }^{(29)}$; and boutique manufacturers' (new, small, independent entrants to the pasta sauce category with an assumed small market share).

\section{Data analysis}

The mean, median, range and standard deviation for $\mathrm{Na}$ in pasta sauces (mg Na/100 g) were calculated overall, by type of pasta sauce, by manufacturer and manufacturer type for 2008 and 2011 using IBM SPSS Statistics Version $19 \cdot 0$. The means for ambient, fresh and total pasta sauces were compared between years using Student's unpaired $t$ test and where the same products were present in both years using Student's paired $t$ test. A two-sided $P$ value of $<0.05$ was taken as significant. The percentage of products with $\mathrm{Na}$ levels greater than the 'action point' was identified for 2008 and 2011. Likewise, the percentage of products meeting the 2012 UK Na target for pasta sauces of $330 \mathrm{mg} / 100 \mathrm{~g}$ was also calculated.

A 2011 baseline was established upon which to project the FHD commitment. The products above $420 \mathrm{mg} \mathrm{Na}$ / $100 \mathrm{~g}$ in 2011 were identified and the FHD target of a $15 \%$ reduction was applied to project a 2014 mean (scenario 1). In addition, to assess the potential impact of the FHD commitment for market leaders to seek opportunities and reduce $\mathrm{Na}$ in leading products already below 
$420 \mathrm{mg} \mathrm{Na} / 100 \mathrm{~g}$, a reduction of $15 \%$ was also applied to all products from leading manufacturers with less than $420 \mathrm{mg} \mathrm{Na} / 100 \mathrm{~g}$ in 2011 (scenario 2). The projected mean Na values for the 2014 FHD commitment were compared against the 2012 UK Na target for pasta sauce.

\section{Results}

$\mathrm{Na}$ data were available for 124 pasta sauce products in 2008 and 187 in 2011. Of these, twenty-five were the same products present in both years with the remainder present only in one year or the other. The great majority of products in both years were classified as ambient pasta sauces (86\%). Of the 159 ambient products for sale in 2011, other manufacturers and boutique manufacturers provided approximately $15 \%$ each, supermarket own label $24 \%$ and leading manufacturers $43 \%$. Overall the data were normally distributed. The mean Na content for all pasta sauces in 2011 was $423 \mathrm{mg} / 100 \mathrm{~g}$ and in 2008, $451 \mathrm{mg} / 100 \mathrm{~g}(P=0 \cdot 16$; Table 1$)$, with a similar pattern observed for the ambient and fresh subsets. There were no significant differences in the mean $\mathrm{Na}$ content for products present in 2008 and 2011 (439 mg/100 g $v$. $435 \mathrm{mg} / 100 \mathrm{~g} ; P=0.83$ ) or for products present in only 2008 or 2011 ( $454 \mathrm{mg} / 100 \mathrm{~g} v .422 \mathrm{mg} / 100 \mathrm{~g} ; P=0 \cdot 13)$.

There were no detectable differences in the average $\mathrm{Na}$ levels between 2008 and 2011 for products produced by any of the different manufacturer types. The more detailed examination of modifications to the $\mathrm{Na}$ content of pasta sauces by individual manufacturers showed divergent patterns with Mars, for example, reducing mean Na levels by $16 \%(P=0.020)$ but Woolworths increasing by $94 \%$ the mean $\mathrm{Na}$ content in its products from
$265 \mathrm{mg} / 100 \mathrm{~g}$ to $513 \mathrm{mg} / 100 \mathrm{~g}(P<0 \cdot 001)$ over the same period. In contrast, the 2011 mean for Coles $(287 \mathrm{mg} \mathrm{Na} /$ $100 \mathrm{~g}$ ) was almost half that of Woolworths.

\section{Projected impact of the Food and Health Dialogue commitment to reduce $\mathrm{Na}$ in pasta sauce products and a comparison of the results with the 2012 UK target}

When a $15 \%$ reduction was applied to the ninety-seven pasta sauce products exceeding $420 \mathrm{mg} \mathrm{Na} / 100 \mathrm{~g}$ (scenario 1), the projected total category mean for 2014 was $381 \mathrm{mg} \mathrm{Na} / 100 \mathrm{~g}$ compared with the baseline of $423 \mathrm{mg}$ $\mathrm{Na} / 100 \mathrm{~g}$ (Table 2 and Fig. 1). This represents a projected overall 10\% Na reduction in pasta sauces from 2011 to 2014 , but leaves Australian pasta sauces an average $51 \mathrm{mg} / 100 \mathrm{~g}$ (15\%) higher in $\mathrm{Na}$ than was proposed for UK pasta sauces in 2012. The projected mean was almost unchanged (375 mg Na/100 g) when an additional 15\% reduction was applied to the products of leading manufacturers with $\mathrm{Na}$ levels in 2011 already below the $420 \mathrm{mg} \mathrm{Na} / 100 \mathrm{~g}$ action point (scenario 2). The projected range of $\mathrm{Na}$ levels for Australian pasta sauces in 2014 was $31-1020 \mathrm{mg} / 100 \mathrm{~g}$.

In 2008 and 2011 almost three-quarters of products exceeded the UK target of $330 \mathrm{mg} \mathrm{Na} / 100 \mathrm{~g}$, and for Australian products to achieve the 2012 UK target by 2014 would require an across-the-board $22 \%$ reduction from 2011 levels. Approximately half of Australian products that did meet the UK target in 2011 were supplied by boutique manufacturers and the 2011 mean $\mathrm{Na}$ value for this manufacturer type $(325 \mathrm{mg} / 100 \mathrm{~g})$ was already below the 2012 UK target (Table 2). The mean Na values for all three other manufacturer types were substantially higher.

Table 1 Changes in the sodium content of pasta sauces overall and by category in Australia between 2008 and 2011; data collected from five leading grocery stores in Sydney, Australia, in July-September of 2008 and 2011

\begin{tabular}{|c|c|c|c|}
\hline \multirow[b]{2}{*}{ Pasta sauce category } & \multicolumn{2}{|c|}{ Year } & \multirow{2}{*}{$\begin{array}{c}\text { Mean change between } 2008 \text { and } 2011(\mathrm{mg} \mathrm{Na} / 100 \mathrm{~g}) \\
95 \% \mathrm{Cl} \\
P \text { value }^{\star}\end{array}$} \\
\hline & 2008 & 2011 & \\
\hline \multicolumn{4}{|l|}{ Ambient } \\
\hline Number of products & 106 & 159 & \\
\hline Mean $(\mathrm{mg} \mathrm{Na} / 100 \mathrm{~g})$ & 457 & 430 & -27 \\
\hline Range (mg Na/100 g) & $144-1034$ & $31-1200$ & $-15,+68$ \\
\hline$\%>$ FHD action pointt & 58 & 55 & $0 \cdot 20$ \\
\hline$\%$ meeting FSA 2012 targetł & 23 & 23 & \\
\hline \multicolumn{4}{|l|}{ Fresh } \\
\hline Number of products & 18 & 28 & \\
\hline Mean $(\mathrm{mg} \mathrm{Na} / 100 \mathrm{~g})$ & 418 & 388 & -30 \\
\hline Range $(\mathrm{mg} \mathrm{Na} / 100 \mathrm{~g})$ & $140-780$ & $140-830$ & $-75,+137$ \\
\hline$\%>$ FHD action point + & 39 & 34 & 0.56 \\
\hline$\%$ meeting FSA 2012 targetł & 39 & 43 & \\
\hline \multicolumn{4}{|l|}{ All } \\
\hline Number of products & 124 & 187 & \\
\hline Mean $(\mathrm{mg} \mathrm{Na} / 100 \mathrm{~g})$ & 451 & 423 & -28 \\
\hline Range (mg Na/100 g) & $140-1034$ & $31-1200$ & $-11,+66$ \\
\hline$\%>$ FHD action pointt & 56 & 52 & $0 \cdot 16$ \\
\hline$\%$ meeting FSA 2012 targetł & 25 & 26 & \\
\hline
\end{tabular}

${ }^{*} P$ value describing mean Na difference between 2008 and 2011 derived from two-sided unpaired $t$ test.

tFood and Health Dialogue (FHD) action point of $>420 \mathrm{mg} \mathrm{Na} / 100 \mathrm{~g}$.

¥UK Food Standards Agency (FSA) 2012 target (average) of $330 \mathrm{mg} \mathrm{Na} / 100 \mathrm{~g}$. 
Table 2 Projected sodium content (mean and range) for pasta sauces by manufacturer type and expectation that the UK 2012 pasta sauce target will be met by Australia in 2014

\begin{tabular}{|c|c|c|c|c|c|}
\hline & $n$ & $\begin{array}{l}\text { Current Australian } \\
\text { mean } 2011 \\
(\mathrm{mg} \mathrm{Na} / 100 \mathrm{~g})\end{array}$ & $\begin{array}{c}\text { Projected Australian } \\
\text { mean } 2014 \\
(\mathrm{mg} \mathrm{Na} / 100 \mathrm{~g})\end{array}$ & $\begin{array}{l}\text { Projected Australian } \\
\text { range } 2014 \\
(\mathrm{mg} \mathrm{Na} / 100 \mathrm{~g})\end{array}$ & $\begin{array}{c}\text { Projected to meet } \\
\text { UK } 2012 \text { target of } \\
330 \mathrm{mg} \mathrm{Na} / 100 \mathrm{~g} \text { by } \\
2014\end{array}$ \\
\hline \multicolumn{6}{|c|}{ Scenario 1 - all above $420 \mathrm{mg} \mathrm{Na} / 100 \mathrm{~g}$ action point reduced by $15 \%$} \\
\hline Boutique manufacturers & 39 & 325 & 309 & $67-706$ & Yes \\
\hline Other manufacturers & 35 & 502 & 442 & $200-1020$ & No \\
\hline Supermarket own label & 42 & 379 & 342 & $31-562$ & No \\
\hline Leading manufacturers & 71 & 465 & 415 & $252-757$ & No \\
\hline All pasta sauces & 187 & 423 & 381 & $31-1020$ & No \\
\hline \multicolumn{6}{|c|}{ Scenario 2 - scenario 1 plus all other leading brands reduced by $15 \%$} \\
\hline Boutique manufacturers & 39 & 325 & 309 & $67-706$ & Yes \\
\hline Other manufacturers & 35 & 502 & 442 & $200-1020$ & No \\
\hline Supermarket own label & 42 & 379 & 342 & $31-562$ & No \\
\hline Leading manufacturers & 71 & 465 & 398 & $214-757$ & No \\
\hline All pasta sauces & 187 & 423 & 375 & $31-1020$ & No \\
\hline
\end{tabular}

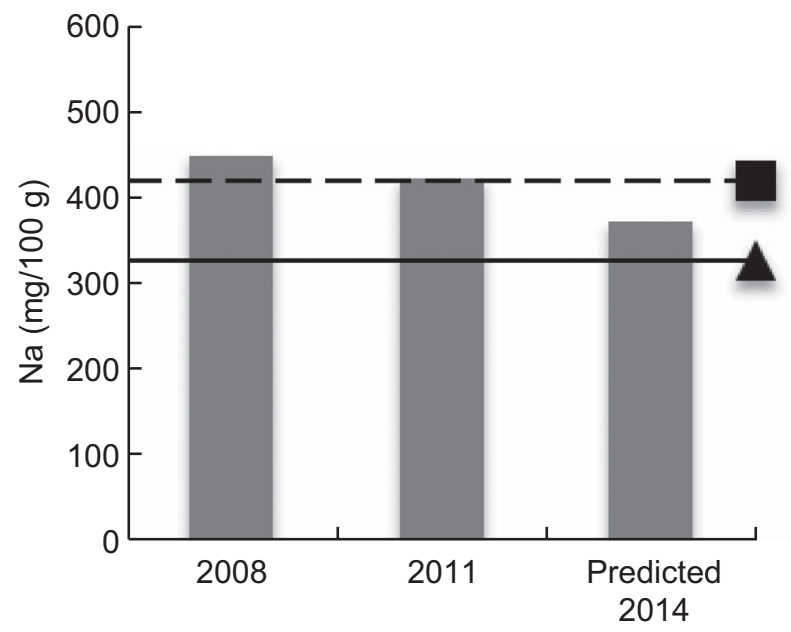

Fig. 1 Mean sodium content $(\square)$ of all pasta sauces in five leading grocery stores in Sydney, Australia, in July-September of 2008 and 2011, and projection for 2014 measured against the Food and Health Dialogue (FHD) commitment of a $15 \%$ reduction for 2014 ( $---\mathbf{E}$, FHD action point) and the 2012 UK target set by the Food Standards Agency ( $\mathbf{\Delta})$

\section{Discussion}

$\mathrm{Na}$ levels in Australian pasta sauces are high and the strategy to reduce them is projected to have little impact. Despite manufacturers responsible for $85 \%$ of Australian market share participating ${ }^{(19)}$ and voluntarily signing up to the government's plan, it is projected that only a $10 \%$ ( $42 \mathrm{mg} \mathrm{Na} / 100 \mathrm{~g}$ ) reduction will be achieved by 2014. As an Australian Federal Government initiative, the Executive of the FHD is chaired by the Parliamentary Secretary for Health and Ageing ${ }^{(30)}$. Government leadership has been identified as one requirement for successful food reformulation initiatives ${ }^{(16)}$. Success, however, can be tempered by food industry lobbying to influence government-led voluntary food reformulation strategies in favour of food industry interests, which can include lack of transparency or rigour in target setting and monitoring ${ }^{(31,32)}$.

\section{Target setting and monitoring}

The FHD has adopted the principle of establishing salt reduction targets, but the method of implementation requires improvement. When done properly, a targetsetting process can provide a much-needed level playing field for industry ${ }^{(7)}$ and an indisputable benchmark against which progress can be tracked.

A level playing field requires absolute, quantitative targets, such as those introduced in the $\mathrm{UK}^{(8)}$ which encourage larger $\mathrm{Na}$ reductions in the saltiest products. On the other hand, the Australian approach of a single $15 \%$ reduction for products above $420 \mathrm{mg} \mathrm{Na} / 100 \mathrm{~g}$ before the end of 2014 allows the highest $\mathrm{Na}$ products to remain as such and creates an unfair competitive advantage based on taste, given the preference for a salty taste being a key driver of food choice ${ }^{(33)}$. Our projections for 2014 show that the FHD commitment may deliver reductions that are only a fraction of those targeted for the UK and that those lesser reductions are likely to lag behind $\mathrm{Na}$ reduction efforts in the UK. There is a striking commonality between pasta sauce products in the UK and Australian markets, but $\mathrm{Na}$ reduction has been on the UK government agenda since 2003. The UK first introduced national voluntary targets in 2006 , and other countries ${ }^{(9,10)}$ have drawn from the strengths of the UK strategy. The FHD commitment to Na reduction is more recent but may benefit by considering the strengths of other approaches. Multiple reductions of 10-15\% can re-set population levels of salt perception and largely go unnoticed by consumers ${ }^{(33)}$. Reduction by stealth was exemplified by Project Neptune $^{(34)}$, led by the Food and Drink Federation, in collaboration with government and public health, and targeted a $30 \% \mathrm{Na}$ reduction in UK ambient cooking and pasta sauces between 2003 and 2006 (10\% per year). Independent market research data (2006-2007) reported a 29\% reduction $^{(34)}$. If the same $30 \%$ reduction target, spread over three years, was adopted by the FHD, the overall projected mean $\mathrm{Na}$ value in 2014 would be $296 \mathrm{mg} / 100 \mathrm{~g}$ and directly comparable to the level already achieved by Australia's 
boutique manufacturers and Coles. In this way the food industry could continue to provide time-poor consumers lacking cooking skills or the inclination to $\operatorname{cook}^{(35,36)}$ with convenience products like pasta sauces without them being significantly detrimental to health.

Methods used to monitor reformulation strategies also differ between countries. However, inadequate rigour in the implementation of many monitoring systems weakens the evidence base and any subsequent conclusions that can be drawn from it. The UK FSA ${ }^{(20)}$ used a variety of monitoring methods including commitment tables, industry self-report against commitments, and food composition databases. Pledges and annual industry self-report are similarly used by the Responsibility Deal ${ }^{(19)}$, making it possible to see which companies have pledged to reduce $\mathrm{Na}$ and what percentage of their products meet the UK 2012 target. The FHD cites industry self-report and reporting of sales/recipes at pre-agreed intervals ${ }^{(19)}$, but to date ${ }^{(11,19)}$ has not published results in a way that would hold companies publicly accountable for the Na reduction commitment they have made to Australians.

\section{Public bealtb nutrition and profit}

All companies need to be financially viable to be sustainable and provide employment. However, many people, including academics and health professionals ${ }^{(14,37-39)}$, are questioning the addition of large quantities of salt (along with saturated fat and sugar) as a mechanism for delivering profit at the expense of nutritional content and health outcome. Salt is required for processing, preservation and sensory perception ${ }^{(40)}$ yet when used in excess, some argue, allows for cheaper ingredients and prolonged shelf-life, tactics that can reduce the cost of goods at the expense of health ${ }^{(14)}$. Our study provides no evidence to support or refute this argument. However, it does provide evidence that companies have not systematically reformulated to reduce the $\mathrm{Na}$ content of products between 2008 and 2011.

A comprehensive approach to target setting and strong government leadership has the potential to provide traction across the food supply and lower barriers to reformulation. Cost is one such barrier, and the cost to reformulate can vary widely but typically includes product development (labour, samples, testing, analysis) and labelling ${ }^{(41)}$. In our study the products with the lowest mean Na levels in 2011 were supplied by boutique manufacturers $(325 \mathrm{mg} / 100 \mathrm{~g})$ and Coles $(287 \mathrm{mg} / 100 \mathrm{~g})$, a supermarket own label producer. It is unclear why one of the large supermarkets and boutique manufacturers (often small enterprises) were able to reduce the $\mathrm{Na}$ content in their products more effectively than other manufacturer types, but it does demonstrate the feasibility of overcoming technical and consumer acceptance issues related to the preparation of lower $\mathrm{Na}$ products. The supermarket own label producers and leading manufacturers hold more than half of the Australian pasta sauce market volume share and it is primarily their actions that will determine the success or failure of the FHD commitment. Some leading manufacturers have made a start in Na reduction, with Mars and Simplot showing trends in the right direction. However, the increase in $\mathrm{Na}$ in Woolworths' products between 2008 and 2011 is of concern and highlights the need for sector-wide action. Marked diversity in the approaches to salt reduction taken by manufacturers has previously similarly been demonstrated for breads ${ }^{(23)}$, fast foods ${ }^{(24)}$ and ready meals ${ }^{(25)}$.

On this basis, standardization of action should be considered in any future review of the FHD strategy that considers optimal ways of engaging the food industry to reduce $\mathrm{Na}$ in processed foods. Working with the food industry to address high $\mathrm{Na}$ intake is a priority for many countries and the UK has been a world-leader in the field. The UK has reduced population salt intake by about $10 \%$ over the last decade primarily through salt reductions to processed foods ${ }^{(42)}$. It is important that this momentum continues and that the pressure on the food industry is maintained now that the responsibility for $\mathrm{Na}$ reduction has been moved from the FSA to the Responsibility Deal.

A key strength of the present study is that data collection occurred within three months of the announcement of the FHD pasta sauce target and thereby provides a contemporary baseline to track future progress and upon which to make projections. Robust interim assessment should be possible for 2012 and $2014^{(19)}$ when Australian manufacturers agreed to report progress, and data are also independently monitored ${ }^{(21)}$. Data for 2009 and 2010 were excluded from the analysis and while including these data provides for more data points, including them did not alter the primary finding. Had our study also included other product types, such as processed meat products where the Na reduction target was announced at the same time as pasta sauces, it is possible we could have gained a richer and broader understanding of the implication of the FHD Na recommendations. That said, concentrating only on pasta sauce products provides for a focused analysis of one industry sector, as it is very likely that technical barriers and opportunities for Na reduction differ across sectors. Applying standards from other countries, in this case the UK, objectively describes how the Australian process stacks up against a directly relevant world-class model being considered by several other countries $^{(43)}$. Market share data for individual products were unavailable to us and appear unlikely to become available to public health over the next few years as the cost is prohibitive. Weighting of the analyses by sales will not therefore be possible and analyses based on means may result in over- or underestimation of effects. However, prior comparison between $\mathrm{Na}$ levels based on crude means and weighted data did not show markedly different findings ${ }^{(44)}$. In projecting (scenario 2 ) we elected to reduce all products from leading manufacturers with a $2011 \mathrm{Na}$ content less than the 'action point' by $15 \%$, 
although the FHD makes no specific recommendation. This reduction was chosen as consistent with the published criteria for products with $\mathrm{Na}$ levels above the 'action point' and was also in line with results from a recent dietary model that reported a $10 \%$ or greater reduction would benefit consumers who were brand loyal ${ }^{(45)}$. A previous study ${ }^{(46)}$ identified inaccuracies in nutrition labelling, although the number of errors is likely to be low and the impact on the study conclusions small. Coverage of Australian pasta sauce products is unlikely to be complete although sampling from the flagship stores of leading Australian supermarket chains means that the analysis includes the majority of pasta sauce products likely to be consumed.

\section{Conclusion}

While some manufacturers have been proactive and reduced $\mathrm{Na}$ levels of their products over recent years, there is little evidence of a systematic effort by all manufacturers. The coming together of government, the food industry and public health groups to establish targets for salt as part of the FHD indicates wide-ranging commitment to tackle high salt consumption in Australia. However, our research clearly demonstrates that manufacturers will need to reformulate pasta sauce products well beyond the FHD commitment if changes are to contribute importantly to national $\mathrm{Na}$ reduction efforts. Government leadership to motivate and reduce barriers to reformulation, together with the implementation of targets to establish a level playing field and transparent systematic monitoring of salt levels in foods, are crucial ways to strengthen the FHD commitment outcome.

\section{Acknowledgements}

Sources of funding: H.T. completed this work as part of the requirements for a Master of Human Nutrition degree at Deakin University, supervised by Dr Mark Kestin. H.T. is supported by a National Health and Medical Research Council Postgraduate Scholarship. E.D. is supported by a Sydney Medical School Foundation scholarship, J.W. is supported by a National Heart and Stroke Foundation postdoctoral fellowship, B.N. is supported by an Australian Research Council Future Fellowship. Conflicts of interest: H.T. is a Research Assistant, E.D. is the Research Officer, J.W. is the Senior Project Manager and B.N. is the Chairman of the Australian Division of World Action on Salt \& Health (AWASH). J.W. was previously responsible for implementing the UK FSA salt reduction strategy. Authors' contributions: H.T. and E.D. designed the study and wrote the first draft of the paper. H.T. and E.D. were responsible for the collation of the data, H.T. did the data analysis. All authors provided input into subsequent drafts. Acknowledgements: The authors thank Anthea Christoforou for her help in reviewing the manuscript.

\section{References}

1. Beaglehold R, Bonita R, Horton R et al. (2011) Priority actions for the non-communicable disease crisis. Lancet 377, 1438-1447.

2. He F \& MacGregor GA (2009) A comprehensive review on salt and health and current experience of worldwide salt reduction programmes. J Hum Hypertens 23, 363-384.

3. Australian Institute of Health and Welfare (2010) Australia's health 2010: the health of Australians - an overview. http:// www.aihw.gov.au/WorkArea/DownloadAsset.aspx?id= 6442452952 (accessed June 2013).

4. Australian Institute of Health and Welfare (2011) Cardiovascular disease: Australian facts 2011. http://www.aihw. gov.au/publication-detail/?id=10737418510\&tab=2（accessed June 2011).

5. Neal BC (2011) Don't spare the salt? Med J Aust 195, 111-112.

6. Brown IJ, Tzoulaki I, Candeias V et al. (2009) Salt intakes around the world: implications for public health. Int $J$ Epidemiol 38, 791-813.

7. Webster JL, Dunford EK, Hawkes C et al. (2011) Salt reduction initiatives around the world. J Hypertens 29, $1043-1050$.

8. Food Standards Agency (2008) Revised Salt Targets. London: FSA; available at http://www.food.gov.uk/multimedia/ spreadsheets/salttargets20102012.xls

9. New York City Department of Health and Mental Hygiene (2011) National salt reduction packaged food categories and targets. http://www.nyc.gov/html/doh/downloads/ pdf/cardio/cardio-salt-nsri-packaged.pdf (accessed January 2011).

10. Health Canada (2012) Guidance for the Food Industry on Reducing Sodium in Processed Foods. Ottawa: Bureau of Nutritional Sciences Food Directorate Health Products and Food Branch.

11. Australian Government, Department of Health and Ageing (2011) Food and Health Dialogue, About us. http:// www.foodhealthdialogue.gov.au/internet/foodandhealth/ publishing.nsf/Content/about-us (accessed September 2011).

12. Strazzullo P, D'Elia L, Kandala NB et al. (2009) Salt intake, stroke, and cardiovascular disease: meta-analysis of prospective studies. BMJ 339, b4567.

13. Keogh JB \& Clifton PM (2008) Salt intake and health in the Australian population. Med J Aust 189, 526.

14. He FJ \& MacGregor GA (2010) Reducing population salt intake worldwide: from evidence to implementation. Prog Cardiovasc Dis 52, 363-382.

15. National Health and Medical Research Council of Australia (2003) Dietary guidelines for Australian adults. http:// www.nhmrc.gov.au/_files_nhmrc/publications/attachments/ n33.pdf (accessed June 2013).

16. Webster J, Dunford E, Huxley R et al. (2009) The development of a national salt reduction strategy for Australia. Asia Pac J Clin Nutr 18, 303-309.

17. National Heart Foundation of Australia (2010) Cooking Sauces. https://www.heartfoundation.org.au/SiteCollection Documents/Tick-cooking-sauces.pdf (accessed June 2013).

18. WHICH (2012) Responsibility Deal: One Year On. An assessment of the Government's approach to healthier food choices. http://www.actiononsalt.org.uk/news/Salt $\%$ 20in\%20the\%20news/2012/70008.pdf (accessed February 2013).

19. Australian Government, Department of Health and Ageing (2011) Nutrition and Healthy Eating; category action plan simmer sauces. http://www.health.gov.au/internet/main/ publishing.nsf/Content/cat-action-plan-sauce (accessed May 2011). 
20. Food Standards Agency (2009) UK Salt Reduction Initiatives. London: FSA; available at http://www.food.gov.uk/ multimedia/pdfs/saltreductioninitiatives.pdf

21. The George Institute for Global Health (2008) Food Composition Database. Sydney: The George Institute for Global Health.

22. Dunford E, Eyles H, Mhurchu NC et al. (2011) Changes in the sodium content of bread in Australia and New Zealand between 2007 and 2010: implications for policy. Med J Aust 195, 346-349.

23. Dunford E, Webster J, Barzi F et al. (2010) Nutrient content of products served by leading Australian fast food chains. Appetite 55, 484-489.

24. Grimes CA, Campbell KJ, Riddell LJ et al. (2011) Sources of sodium in Australian children's diets and the effect of the application of sodium targets to food products to reduce sodium intake. Br J Nutr 105, 468-477.

25. Christoforou AK, Dunford EK \& Neal BC (2013) Changes in the sodium content of Australian ready meals between 2008 and 2011. Asia Pac J Clin Nutr 22, 138-143.

26. Webster JL, Dunford EK \& Neal B (2010) A systematic survey of the sodium contents of processed foods. Am J Clin Nutr 91, 413-420.

27. Consumer Action on Salt and Health (2009) Pasta Sauce Survey Data. London: Wolfson Institute of Preventive Medicine.

28. Dunford E, Webster J, Metzler AB et al. (2012) International collaborative project to compare and monitor the nutritional composition of processed foods. Eur J Cardiovasc Prev Rehabil 19, 1326-1332.

29. Retail Media Pty Ltd (2009) Retail World's Australasian Grocery Guide. Sydney: Retail Media Pty Ltd.

30. Appelqvist I, Lundin L, Margetts C et al. (2011) A Review of Initiatives Being Undertaken Nationally and Internationally to Address Poor Dietary Intake. Canberra: Australian Government, Department of Health and Ageing.

31. Lawrence M (2009) Do food regulatory systems protect public health? Public Health Nutr 12, 2247-2249.

32. O'Neill M (2011) Food lobby accused of blocking health reforms. http://www.abc.net.au/news/2011-06-23/food-lobbyaccused-of-blocking-health-reforms/2768170 （accessed February 2013).

33. Liem DG, Miremadi F \& Keast RSJ (2011) Reducing sodium in foods: the effect of flavor. Nutrients 3, 694-711.
34. Food and Drink Federation (2011) The Facts, Salt: industry's efforts make a difference. https://www.fdf.org. uk/resources/salt-thefactsfinal1.pdf (accessed June 2013).

35. Lang $\mathrm{T} \&$ \& Caraher $\mathrm{M}$ (2001) Is there a culinary skills transition? Data and debate from the UK about changes in cooking culture. J HEIA $\mathbf{8}, 2-14$.

36. Caraher M, Baker H \& Burns M (2004) Children's views of cooking and food preparation. Br Food J 106, 255-273.

37. Brownell KD (2012) Thinking forward: the quicksand of appeasing the food industry. PLoS Med 9, e1001254.

38. Stuckler D \& Nestle M (2012) Big food, food systems, and global health. PLoS Med 9, e1001242.

39. Moodie R, Stuckler D, Monteiro C et al. (2013) Profits and pandemics: prevention of harmful effects of tobacco, alcohol, and ultra-processed food and drink industries. Lancet 381, 670-679.

40. Hutton T (2002) Sodium: technological functions of salt in the manufacturing of food and drink products. $\mathrm{Br}$ Food J 104, 126-152.

41. Food Standards Agency (2009) Summary: Interventions \& Options; Impact Assessment of the Revised Salt Reduction Targets. London: FSA; available at http://www.food.gov. $\mathrm{uk} /$ multimedia/pdfs/consultation/iarevsaltredtargets19jun09. pdf

42. Shankar B, Brambila-Marcias J, Traill B et al. (2013) An evaluation of the UK Food Standards Agency's salt campaign. Health Econ 22, 243-250.

43. Campbell NRC, Neal BC \& MacGregor GA (2011) Interested in developing a national programme to reduce dietary salt? J Hum Hypertens 25, 705-710.

44. Mhurchu CN, Capelin C, Dunford EK et al. (2011) Sodium content of processed foods in the United Kingdom: analysis of 44,000 foods purchased by 21,000 households. Am J Clin Nutr 93, 594-600.

45. Australian Government, Department of Health and Ageing (2012) Food and Health Dialogue Communique. http:// www.health.gov.au/internet/ministers/publishing.nsf/Content/ mr-yr12-ck-ck013.htm?OpenDocument\&yr $=2012 \& \mathrm{mth}=12$ (accessed May 2012).

46. Food Standards Australia New Zealand (2012) Sodium levels in a range of packaged and take-away foods. http://www. foodstandards.gov.au/scienceandeducation/publications/ sodiumlevelsinarange4648.cfm (accessed May 2012). 